\title{
Care and the Neoliberal Individual
}

\author{
Mary V. Wrenn \\ Senior Lecturer in Economics \\ University of the West of England \\ mary.wrenn@uwe.ac.uk \\ William Waller \\ William R. Kenan, Jr. Professor of Economics \\ Hobart and William Smith Colleges \\ waller@hws.edu
}

Key words: care, autonomy, neoliberalism, Veblen, institutionalism

JEL: B52, N32, P10, Z10

\begin{abstract}
:
This research explores two conflicting ethical systems. Neoliberalism's foundations support an overarching ethic of individual autonomy and individual responsibility. Institutionalism contrasts this conception with a view of human beings as relational. The ethical foundation of such a view requires a meta-ethic of interpersonal responsibility that supports an ethic of care.
\end{abstract}

Biographical note:

William Waller is the William R. Kenan, Jr. Professor of Economics at Hobart and William Smith Colleges. Mary V. Wrenn is a Senior Lecturer in Economics at the University of the West of England. This paper was presented at the annual meeting of the Association of Evolutionary Economics, January 2017 in Chicago. 
Humans in their natural states possess the capacity for selfishness and the capacity for communal care. That individuals exhibit either selfish or other-regarding behavior, speaks to the surrounding institutional configuration. Capitalism is justified by the insistence on autonomy as the natural state of humans. Our argument is simple: the instinct and ethic of care stands counter to capitalism and is pathological in neoliberalism.

\section{Human Nature}

The theory of human nature an ideology espouses has implications for what behavior is emergent from that nature. Behavior consistent with the conception of human nature is natural. Behavior that does not emerge from that conception of human nature is unnatural and is often considered pathological.

Neoliberalism postulates a specific vision of human nature. Individuals are self-interested and proceed in the service of this self interest in atomistic, individualistic terms. This conception is often assumed as self-evident truth and is a part of a simplistic argument in favor of autonomy. Veblen critiqued this conception and argued that 'economic man' has no history or cultural context to structure or affect his choices. (Veblen 1990a) This characterization of human nature precludes the human relations that constitute caring. Indeed this characterization essentially defines such relationships as unnatural.

\section{Instincts, behavior, and institutions}

Veblen argued that human behavior was motivated by instincts. ${ }^{1,2}$ Instincts have recently been reclaimed and renamed as adaptations by evolutionary psychologists (see Waller 2017). The structure of human behavior develops because some element of the environment triggers an instinct that forms the motivation. Responding to this motivation is a problem to be solved. The appropriate behavior needs to be discovered or drawn from the existing cultural repertoire of solutions.

Of particular importance is the instinct Veblen called the parental bent. The parental bent for Veblen is the proclivity "to the achievement of children" and "a primary element in the practical working out of parental solicitude" (Veblen 1990b, 26). Veblen argued that this solicitude was extended beyond the scope of children to the well-being of the community (Veblen 1990b). This conception of human nature allows us to consider behavior characterized by care which supports and reinforces a social ethic of care. The relationship between the parental bent and care has recently been explored by Cumbers, Davis and McMasters (2015).

\section{Care}

In their recent article, Cumbers et al. makes the overlap of interests between theorists of care and institutional economists clear (2015). The authors locate care as a neglected aspect of institutional economics. They argue that care is undervalued and that austerity 
programs increase the need for care thereby expanding our caring deficit. A care deficit is also identified by Joan Tronto (2013).

There are many definitions of care. Cancian and Oliker define care as the "feelings of affection and responsibility combined with actions [that] provide responsively for an individual's personal needs or well-being, in a face-to-face relationship" (2000, 2). This definition captures the affective quality of care and combines it with action. Folbre and Wright stress care as both activities and a state of being: "Our categorization ... calls attention to both the labor process and the direct beneficiary of service provided" (2012, 45). Noddings adds to the definition of care emphasizing receptive attention to the needs of another characterized by motivational displacement: the care giver temporarily abandons self-interest and replaces it with the interests of the care-receiver (2002).

Of interest for our purposes, Cumbers et al. argued that Joan Tronto's influential definition of care (Tronto 1993, 2013) has an affinity to the social value principle articulated by Marc Tool. (Cumbers, et al. 2015). That definition is:

On the most general level, we suggest that care be viewed as a species activity that includes everything that we do to maintain, continue, and repair our world so that we can live in it as well as possible. That world includes our bodies, our selves, and our environment, all of which we seek to interweave in a complex, life-sustaining web. (Tronto 1993, 103 emphasis in original)

The beginning of the definition it is expressly non-individualistic, defining care as a species activity. This corresponds to Veblen's notion of care emerging from the parental bent-part of the biological hardwiring of all human beings.

Beyond these Veblenian notes, the real tie to institutionalism is through the similarities to the social value principles articulated by institutionalists. In particular, the injunction that we maintain, continue and repair our world correlates with Marc Tool's social value principle $(1995,23)$ : "Do or choose that which provides for the continuity of human life and the noninvidious re-creation of community through the instrumental use of knowledge." Cumbers, et al. note that the "continuity" in Tool's social value principle has an "obvious correspondence to Tronto's references to 'maintain' and 'continue.' There are reproductive and moral imperatives inherent in both" $(2015,586)$.

Both definitions focus on the continuity of life (Tool) and the maintenance of the environment in which that life is maintained, continued, and repaired (Tronto) with Tool adding environmental compatibility into his corollaries to his social value principle (Tool 1979).

Tronto argues adequate care recognizes human beings are relational. Care involves a complex, interrelated series of actions including: attention to the needs of others; accepting responsibility for meeting those needs; acting to fulfill those needs; and relational reciprocation with those receiving care. Within caregiving, competence of the caregiver is required to sustain an ethic of care (Tronto 1993). This corresponds to acting on the basis 
of the instrumental use of knowledge and acting with instrumental efficiency in Tool (Tool 1979).

We can see that there is a strong connection between the social value principle of Marc Tool's and Joan Tronto's definition of care. Tronto argues that:

To be a morally good person requires, among other things, that a person strives to meet the demands of caring that present themselves in his or her life. For a society to be judged as a morally admirable society, it must, among other things, adequately provide for care of its members and its territory (Tronto 1993, 126).

Tronto argues that it would be good if an ethic of care were elevated to a primary ethical principle in our society.

Institutionalists make a stronger claim. First, Veblen argues that care is an instinct based activity-a necessary, genetic disposition. Second, Tool argues that instrumental valuation is a social inevitability (Waller 2013). As a consequence, if a culture is to survive and thrive it must adopt an ethic of care.

Tronto's analysis directly attacks neoliberalism by rejecting the public/private dualism that assigns all caring responsibility to the private aspect of family life thereby limiting the social input and assignment of responsibility to highly gendered familial relations. Similarly, she sees a limited role for the market in the assignment of caring responsibilities and the provision of care. The market system presumes the individual character of caring responsibility for the provision of care. The market reinforces (when it does not actually create) the individualistic character of contemporary caring. The market assumes every individual has the same capacity to assess needs and provide care. The market reinforces the public/private dualism. The market fails at pricing care both as a public good and externalities. The market reinforces existing structural inequalities and existing hierarchies. Finally, Tronto notes the market ignores the relational character and the time dimension of caring. (Tronto 2013)

\section{Autonomy}

Autonomy is a state of being or a condition of life, not an ethic. It conceptually grows out of the individualistic conception of human beings; what Paula England called "the separative self" (England 2003). This is a theory of human nature and action which is the foundation of the assumption that the ideal state for a person is one of autonomy: it supports ethics of self-interest and personal, individual responsibility. Certainly selfinterest has survival value and has a foundation in instinctual behavior. Similarly, personal responsibility is a desirable ethical principle. However, within neoliberalism this ethic of personal responsibility takes on the role of a theory of cause and effect with regard to all human activity. A person's situation is entirely determined by their individual actions. There is, in this theory of behavior, no causation related to history or context. 
As an accurate, historical reflection of human life, the individualistic conception of the autonomous individual fails completely. Human beings are "relational" (Noddings 2002, 97-103). Our lives begin with a dyadic relationship with our mother that expands into a network of relationships that define us and structure our behavior within the context of those relationships. Much activity is directed at sustaining and expanding those relationships. This is done partially by continually providing and receiving care. The need for care is a universal fact-of-life for humans. From this we can reject the conception of people as merely autonomous individuals as a basis for theorizing.

Just as an ethic of self-interest supports autonomous action by individuals, an ethic of care supports relational activity among individuals. Autonomy as a state of being fosters an ethic of personal responsibility. Similarly, people in relationships with others foster an ethic of care. Human experience has room for both; human nature seems to contain instinctual elements of both. But neoliberalism valorizes individual autonomy and selfinterest and asserts its normative superiority while treating care as a sign of individual defect. Within neoliberalism, care as a social activity is seen as fostering dependency and is therefore pathological. Thus, social caring is outside the realm of neoliberal conceptions of normal behavior or policy.

\section{Neoliberalism and the disembedded economy}

Neoliberalism as an ideology valorizes autonomy as a state of being and ethics of selfinterest and personal responsibility exclusively. It crowds out an ethic of care. Let us consider the consequences of neoliberal theory on behavior in society.

Within neoliberalism, the economic sphere dominates. Natural rights are contextualized and redefined through economic terms - the natural workings of the market. Likewise with the concepts of liberty, democracy, freedom - all are cast as essentially economic. The essence of liberty, democracy, freedom, justice are immutably situated within the market (Brown 2015).

The institutionalization of the market changes the institutional structures through which individuals are socialized. The expanding economic sphere pervades the lives and thinking of individuals. As such, the socialization process becomes accommodating to the intensifying market place and the transference of culture all becomes tinged by the values of the market.

This momentum of market intensification of capitalism encourages the disembedding of the economic sphere. The economic sphere enlarges, encompassing the entirety of social life, subordinating the other spheres of livelihood (Polanyi 2002). The market mentality and the continued disembedding of the economy drives a wedge into the development of personal relationships as the anonymity of the market, pecuniary values, and the competition of emulation distance individuals from one another (Stanfield and Stanfield 1996). Polanyi wrote about capitalism prior to the emergence of neoliberalism, but his description of the disembedded economy describes how neoliberalism emerged and evolves 
(Dale 2010). The superiority of the individual over the collective is the guiding principle of neoliberalism.

\section{Neoliberalism as ideology}

Neoliberalism is the prevailing ideological operant in this stage of the evolution of capitalism. Neoliberalism embodies the ideological shift in the purpose of the state from a responsibility to protect its citizens against the exigencies of the market to insuring protection of the market itself (Harvey 2005).

The neoliberal narrative consists of three well-defined tropes: privatization of state provided goods and services, de-regulation of industry, and retrenchment of the welfare state (Dumenil and Levy, 2011). All three reinforce a central premise: the locus of control is the individual exercising agency through market operations. The tropes of privatization and de-regulation both argue that erecting a wall between government and business creates a more efficient market economy; private industry is brought to heel by competitive market forces that represent the aggregate of individual decisions. Likewise, the retrenchment of the welfare state erects a wall between the individual and the state (Wrenn 2016).

This analysis of the neoliberalism does not suggest there is a comprehensive 'Neoliberal Agenda' that is actively enforced. Rather, what is argued is that the neoliberalism consists of an ideological construct - that of primal individualism - upon which the justification of these tropes rests. Neoliberalism teaches through the socialization process that each individual should be accountable to herself and in so doing, each individual's responsibility to others and to the collective is eroded. Society is then comprised solely of self-interested, atomistic individuals seeking to forward their own agendas. The emphasis on individual accountability and responsibility naturally segues into the power of the individual acting alone.

This ethos of primal individualism systematically dismantles the power of collective action for the general population while protecting the power of collective action among corporate entities, industries, or the interests of capital writ large.

\section{The neoliberal human}

Neoliberalism valorizes autonomy and the ethic of self-interest and personal responsibility. These are important ethical principles in our culture, but in neoliberalism they become hegemonic. Other ethical principles, especially those that run contrary to the ethic of autonomy are seen as unnatural and pathological. By pathological we mean that other ethical considerations are only legitimate to the degree they can be reconciled with autonomy. Many ethics are truncated to be reconciled with autonomy and are discarded when they cannot.

Care involves the care giver's consciousness being characterized by motivational displacement (Noddings 2002). The care giver abandons their self-interest and takes up as 
their motivation the needs of the cared-for. Then a relationship exists where the care giver abandons their autonomy and the cared-for has lost their autonomy temporarily. The goal in neoliberal culture is the restoration of both the care giver's and the cared-for's autonomy. So the need for care is fundamentally pathological-to be repaired or overcome. Those whose loss of autonomy is prolonged are treated as non-participants in the social milieu. If the loss of autonomy is not rectified, the exclusion can be permanent.

\section{Concluding remarks}

The apparent contradiction between autonomy and care is based on a confusion of type. Autonomy is a state of being. If this condition of life is valorized, then ethical principles flow from it. These include self-interest and personal responsibility. Care is an action, often conceived in terms of a process. It is a response to another state of being, namely dependency. Dependency is normal and the response to dependency, care, has biological origins. From these facts-of-life we derive an ethic of care. Care is obviously relational, but autonomy is also relational-it is a relationship between one person and all the others in that person's society. The conflict is not between a state of being (autonomy) and an action (care), but instead between two states of being, autonomy and dependency. Within neoliberalism the ubiquitous dependency that exists is demonized while autonomy is valorized. It is this imagining that casts personal responsibility and self-interest as fundamentally incompatible with caring behavior in the public realm.

Within neoliberalism, the economic sphere dominates society, so that the ethos of individual responsibility is replicated on all subordinate levels and consequently, the inevitable alienation of neoliberal capitalism is replicated throughout all social spheres. The individual is taught that to have a responsibility for the care of others diminishes one's own identity, constraining the possibilities of the responsible individual. If under neoliberalism the market mentality dominates all other spheres of living, then that collective social identity is circumscribed by neoliberalism as well.

In a more balanced version of human nature there is a role for both autonomy as a state of being and care as an activity. It may be desirable for humans to achieve the capacity for independence; we may valorize the achievement of autonomy and acceptance of personal responsibility. We must also recognize that the human condition is one that inevitably has periods of dependency (particularly childhood, periods of illness or injury, disability, and the natural decline in our capacities as we age). In this version, care as an activity can be thought of as the actions that lead to the development, recovery and the maintenance of autonomy.

\section{References}

Brown, Wendy. 2015. Undoing the Demos: Neoliberalism's Stealth Revolution. Cambridge, MA: MIT Press. 
Cancian, Francesca M. and Stacey J. Oliker. 2000. Caring and Gender. Walnut Creek, CA: AltaMira Press.

Cumbers, Andrew, John Davis and Robert McMasters. 2015. "Theorizing the Social Provisioning Process Under Capitalism.” Journal of Economic Issues. 49(2), Pp. 583-590.

Dale, Gareth. Karl Polanyi: the Limits of the Market. Cambridge: Polity Press, 2010.

Dumenil. G. and Levy, D. 2011. The Crisis of Neoliberalism. Cambridge, MA: Harvard University Press.

England, Paula. 2003. "Separative and Soluble Selves: Dichotomous Thinking in Economics.” Feminist Economics Today: Beyond Economic Man. M.A. Ferber and J.A. Nelson editors. Chicago: University of Chicago Press.

England, Paula, Nancy Folbre and Carrie Leana. 2012. "Motivating Care." For Love or Money: Care Provision in the United States. N. Folbre ed. New York: Russell Sage.

Folbre, Nancy and Erik Olin Wright. 2012. "Defining Care.” For Love or Money: Care Provision in the United States. N. Folbre ed. New York: Russell Sage.

Harvey, David. 2005. A Brief History of Neoliberalism. Oxford, UK: Oxford University Press.

Hodgson, Geoffrey. 1997. "The ubiquity of habits and rules." Cambridge Journal of Economics. 21, Pp. 663-684.

. 2004a. "Reclaiming habit for institutional economics." Journal of Economic Psychology. 25, Pp. 651-660.

. 2004b. The Evolution of Institutional Economics. New York: Routledge. . 2010. "Choice, habit and evolution." Journal of Evolutionary Economics. 2, Pp.

$1-18$.

Lawson, Tony. 2014. "Process, Order and Stability in Veblen" Cambridge Journal of

Economics. First published online on October 1, 2014. doi: 10.1093/cje/beu045

Noddings, Nel. 2002. Starting at Home: Caring and Social Policy. Berkeley: University of California Press.

Polanyi, Karl. 2002. The Great Transformation: The Political and Economic Origins of our Time. $2^{\text {nd }}$ ed. Boston: Beacon Press. 
Stanfield, James Ronald, and Jacqueline Bloom Stanfield. 1996. "Reconstructing the Welfare State in the Aftermath of the Great Capitalist Restoration." In Inequality: Radical Institutionalist Views on Race, Gender, Class, and Nation, edited by W. M. Dugger, 127-139. Westport, Connecticut and London: Greenwood Press.

Tool, Marc R. 1995. Pricing, Valuation and Systems. Cheltenham, UK: Edward Elgar. 1979. The Discretionary Economy. Santa Monica: Goodyear.

Tronto, Joan C. 2013. Caring Democracy: Markets, Equality, and Justice. New York: New York University Press.

Routledge.

1993. Moral Boundaries: A Political Argument for an Ethic of Care. New York:

Veblen, Thorstein. 1990a. "The Limitations of Marginal Utility." The Place of Science in Modern Civilization. New Brunswick: Transactions Press. Pp.231-251.

1990b. The Instinct of Workmanship and the State of the Industrial Arts. [1914]

New Brunswick: Transactions Press.

Waller, William. 1988. "The Concept of Habit in Economic Analysis." Journal of Economic Issues. 22(1), Pp. 113-126.

2013. "The Unreasonable Society: Foster and the Limits of Instrumental Valuation." Journal of Economic Issues. 47(4), Pp. 1003-1010.

. 2016. "Veblen, Instinct and Exchange." Marx, Veblen, and the Foundations of Heterodox Economics. Tae-Hee Jo and Frederic S. Lee eds. New York: Routledge.

2017. "Reconsidering Thorstein Veblen's Use of Instincts." The Annotated Thorstein Veblen. Sidney Plotkin ed. London: Anthem Press. Forthcoming.

Zachorowska-Mazurkiewicz, Anna. 2015. "The Concept of Care in Institutional and Feminist Economics and Its impact on Public Policy." Journal of Economic Issues. 49(2), Pp. 405-413.

Wrenn, Mary V. 2016. "Immanent Critique, Enabling Myths, and the Neoliberal Narrative.” Review of Radical Political Economics. 48(3), pp. 452-466.

\section{End notes}


1. This motivation leads to action, but not a particular action unless the response to the motivation was already well understood and a matter of common knowledge in the culture. If not, the individual would choose a course of action in response to the motivation. If the course of action is effective, then the action might become a habitual response to the stimulus (see Hodgson 1997, 2004a, 2004b and 2010, Waller 1988, 2016, 86-87, Lawson 2014). This would be an individual's habit. When the behaviors are believed and demonstrated to be efficacious they will be adopted. Eventually they become "settled habits of thought common to the generality of men "what Veblen called institutions in "The Limitations of Marginal Utility” (Veblen 1990a, 239).

2. There are a few economists who have paid attention to evolutionary biology but Paula England, Nancy Folbre, and Carrie Leana $(2012,26-27)$ have explicitly made the link from instincts or adaptations as a biological foundation to the motivations for care. 